\title{
The use of biological disease-modifying antirheu- matic drugs for inflammatory arthritis in Korea: results of a Korean Expert Consensus
}

\author{
Eun-Jung Park ${ }^{1}$, Hyungjin Kim² ${ }^{2}$, Seung Min Jung ${ }^{3}$, Yoon-Kyoung Sung ${ }^{4}$, Han Joo Baek ${ }^{5}$, and Jisoo Lee ${ }^{6}$
}

\begin{abstract}
${ }^{1}$ Division of Rheumatology, Department of Medicine, National Medical Center, Seoul; ${ }^{2}$ Department of Medicine, Samsung Medical Center, Sungkyunkwan University School of Medicine, Seoul; ' ${ }^{3}$ Division of Rheumatology, Department of Medicine, Yonsei University College of Medicine, Seoul; ${ }^{4}$ Department of Rheumatology, Hanyang University Hospital for Rheumatic Diseases, Seoul; ${ }^{5}$ Division of Rheumatology, Department of Internal Medicine, Gachon University Gil Medical Center, Incheon; ${ }^{6}$ Division of Rheumatology, Department of Internal Medicine, Ewha Womans University School of Medicine, Seoul, Korea
\end{abstract}

Received: December 2, 2019

Accepted: December 23, 2019

Biological disease-modifying antirheumatic drugs (bDMARDs) are highly effective agents for the treatment of inflammatory arthritis; however, they also possess a potential risk for serious infection. Recently, with the rapid expansion of the bDMARDs market in Korea, reports of serious adverse events related to the agents have also increased, necessitating guidance for the use of bDMARDs. Current work entitled, "Expert consensus for the use of bDMARDs drugs for inflammatory arthritis in Korea," is the first to describe the appropriate use of bDMARDs in the management of inflammatory arthritis in Korea, with an aim to provide guidance for the local medical community to improve the quality of clinical care. Twelve consensus statements regarding the use of bDMARDs for the management of rheumatoid arthritis and ankylosing spondylitis were generated. In this review, we provide detailed guidance on bDMARDs use based on expert consensus, including who should prescribe, the role of education, indications for use, and monitoring strategies for safety.

Keywords: Expert consensus; Biological disease-modifying antirheumatic drugs; Inflammatory arthritis; Arthritis, rheumatoid; Spondylitis, ankylosing

\section{INTRODUCTION}

Inflammatory arthritis including rheumatoid arthritis (RA) and ankylosing spondylitis (AS) is a chronic autoimmune disease, which creates a major health burden with negative impact on activities of daily living, quality of life, and utilization of health care resources [1-6]. However, there was a dramatic improvement in the lives of many patients with inflammatory arthritis after the introduction of highly effective agents for treatment, i.e., biological disease-modifying antirheumatic drugs
(bDMARDs) [7-13]. Due to their high efficacy, bDMARDs are used increasingly in the treatment of inflammatory arthritis in a recent decade, but the issues regarding appropriate use, safety and cost have been also raised in parallel [14-17]. The global rheumatology community has realized the importance of these issues regarding bDMARDs use, facilitating the development of several recommendations and guidelines from the major rheumatology societies including the American College of Rheumatology (ACR) [9,10], the European League Against Rheumatism (EULAR) 
Table 1. Significance of the quality of evidence according to the GRADE system $[19,20]$

\begin{tabular}{ll}
\hline Quality level & \multicolumn{1}{c}{ Definition } \\
\hline $\begin{array}{l}\text { High } \\
\text { Moderate }\end{array}$ & $\begin{array}{l}\text { We are very confident that the true effect lies close to that of the estimate of the effect. } \\
\text { of the effect, but there is a possibility that it is substantially different. }\end{array}$ \\
Low & $\begin{array}{l}\text { Our confidence in the effect estimate is limited. The true effect may be substantially different from } \\
\text { the estimate of the effect. }\end{array}$ \\
Wery low & $\begin{array}{l}\text { We have very little confidence in the effect estimate. The true effect is likely to be substantially differ- } \\
\text { ent from the estimate of effect. }\end{array}$
\end{tabular}

GRADE, Grades of Recommendation, Assessment, Development, and Evaluation.

$[12,18]$ and Asia Pacific League of Associations for Rheumatology (APLAR) [13]. As observed globally, reports of inappropriate use and serious adverse events related to bDMARDs were increasingly observed in Korea, with the rapid expansion of the bDMARDs market in the region. The Korean College of Rheumatology (KCR) recognized the urgent need for the development of regional guideline based on scientific evidences to guide the practitioners to use bDMARDs effectively and safely, since the differences in disease manifestations, healthcare resources, and medical insurance systems among countries preclude direct application of international guidelines. In 2018, the task force team has been organized under the auspice of the KCR Heath Policy Affairs Committee to develop an expert consensus for the appropriate use of bDMARDs for inflammatory arthritis in Korea.

In this review, we provide detailed guidance on bDMARDs use in adults with inflammatory arthritis, based on the "Expert consensus for the use of bDMARDs for inflammatory arthritis in Korea" developed by the KCR. Twelve consensus statements regarding the use of $\mathrm{bD}$ MARDs for the management of RA and AS were generated, in consideration of local medical circumstance. The quality of evidence was evaluated using the Grades of Recommendation, Assessment, Development, and Evaluation (GRADE) system (Table 1) [19,20]. We focused on RA and AS because these are the most common inflammatory arthritis in terms of incidence of diseases and the use of biologics agent for treatment $[11,14,15]$. The statements covered four topics: (1) who should prescribe, (2) the role of education, (3) indications for use, and (4) required evaluations before and during use for safety (Table 2). The current consensus statements are the first to describe the appropriate use of bDMARDs in the management of inflammatory arthritis in Korea, with an aim to provide guidance for the local medical community to improve the quality of clinical care.

\section{DEVELOPMENTAL PROCESS}

\section{Korean College of Rheumatology working group}

To develop the expert opinion for use of bDMARDs in patients with inflammatory arthritis, the development group was established on behalf of the KCR. The de velopment group consisted of six rheumatologists and one expert in literature search to collect and evaluate the evidences, and draft the consensus statement. The consensus group consisting of representatives from the relevant stakeholders participated in a voting process to reach a clinical consensus.

\section{Scope of clinical consensus statements}

The clinical consensus statement was developed to improve the quality of health care in patients with RA and AS. The clinical research question was determined using the PIPOH instrument as follows:

Population: Adult patients who were diagnosed with RA or AS according to the previous or current classification criteria [21-24]

Intervention: Treatment with bDMARDs

Professionals: Physicians who treat patients using bDMARDs

Outcomes: Improving the quality of care (efficacy and safety)

Health care setting: all medical settings that prescribe bDMARDs, including community and academic 
Table 2. Expert opinion for the management of inflammatory arthritis in adults with biological disease-modifying antirheumatic drugs ${ }^{a}$ in South Korea

\begin{tabular}{|c|c|c|}
\hline Recommendation & $\begin{array}{l}\text { Appropriateness }^{\mathrm{b}} \\
\text { /median Likert } \\
\text { Scale score }\end{array}$ & $\begin{array}{l}\text { Level of agreement } \\
\quad(\% \text {, agreement })\end{array}$ \\
\hline $\begin{array}{l}\text { 1. bDAMRDs should be prescribed by an expert experienced in the diagnosing } \\
\text { and managing rheumatic diseases, who can monitor disease activity using } \\
\text { standardized assessment tools, and perform safety monitoring (LOE: low; SOR: } \\
\text { strongly recommended). }\end{array}$ & $\mathrm{A} / 9$ & $\begin{array}{l}\text { High agreement } \\
(100)\end{array}$ \\
\hline $\begin{array}{l}\text { 2. Patients should be provided with education about their treatment with } \\
\text { bDMARDs (LOE: moderate; SOR: strongly recommended). }\end{array}$ & $\mathrm{A} / 9$ & $\begin{array}{l}\text { High agreement } \\
(100)\end{array}$ \\
\hline $\begin{array}{l}\text { 3. In RA, if the treatment target is not achieved with the first csDMARDs strategy, } \\
\text { when poor prognostic factors }{ }^{\mathrm{d}} \text { are present, addition of a bDMARD should be } \\
\text { considered (LOE: moderate; SOR: strongly recommended). }\end{array}$ & $\mathrm{A} / 9$ & $\begin{array}{l}\text { High agreement } \\
(100)\end{array}$ \\
\hline $\begin{array}{l}\text { 4. In AS, bDMARDs should be considered in patients with persistently high disease } \\
\text { activity despite conventional treatments including NSAIDs; current practice is to } \\
\text { start with TNF inhibitor therapy (LOE: high for TNF inhibitor/moderate for IL- } \\
17 \text { inhibitor; SOR: strongly recommended). }\end{array}$ & $\mathrm{A} / 9$ & $\begin{array}{l}\text { High agreement } \\
(100)\end{array}$ \\
\hline $\begin{array}{l}\text { 5. In RA, bDMARDs should be combined with a csDMARDs such as MTX(LOE: } \\
\text { high; SOR: strongly recommended). }\end{array}$ & $\mathrm{A} / 9$ & $\begin{array}{l}\text { High agreement } \\
(100)\end{array}$ \\
\hline $\begin{array}{l}\text { 6. In AS, bDMARD monotherapy without csDMARDs is recommended patients } \\
\text { with purely axial disease (LOE: high; SOR: strongly recommended). }\end{array}$ & $\mathrm{A} / 9$ & High agreement \\
\hline $\begin{array}{l}\text { 7. In RA, if a bDMARD has failed, switching to another bDMARD should be } \\
\text { considered (LOE: high; SOR: strongly recommended). }\end{array}$ & $\mathrm{A} / 9$ & $\begin{array}{l}\text { High agreement } \\
(100)\end{array}$ \\
\hline $\begin{array}{l}\text { 8. In AS, if the treatment with the first TNF inhibitor has failed, switching to } \\
\text { another TNF ihibitors or IL-17 inhibitor should be considered (LOE: low for } \\
\text { TNF inhibitor/moderate for IL-17 inhibitor; SOR: weakly recommended for TNF } \\
\text { inhibitors, strongly recommended for IL-17 inhibitor). }\end{array}$ & $\mathrm{A} / 9$ & $\begin{array}{l}\text { High agreement } \\
(100)\end{array}$ \\
\hline $\begin{array}{l}\text { 9. Prior to initiating bDMARDs, disease activity, joint damage, functional } \\
\text { capacity, extra-articular manifestations, comorbidities, vaccination history, and } \\
\text { pregnancy status should be assessed in all patients with inflammatory arthritis }\end{array}$ & $\mathrm{A} / 9$ & $\begin{array}{l}\text { High agreement } \\
(100)\end{array}$ \\
\hline
\end{tabular}

(LOE: low; SOR: strongly recommended).

10. All patients should be screened for active or latent tuberculosis before starting bDMARDs, and if tuberculosis is detected, patients should receive adequate anti-tuberculosis treatment, appropriately (LOE: low; SOR: strongly recommended).

11. All patients should be screened for hepatitis B virus infection before starting bDMARDs, and if hepatitis B virus infection is identified, proper antiviral therapy should be considered(LOE: high for screening/low for antiviral therapy; SOR: strongly recommended).

12. All patients receiving bDMARDs should be monitored for disease activity, joint damage, functional capacity, extra-articular manifestations, comorbidities, and drug side effects and toxicity (LOE: low; SOR: strongly recommended).
$\mathrm{A} / 9$
High agreement $(100)$
A/9 High agreement (100)
A/9 High agreement (100)

bDMARD, biologic disease modifying antirheumatic drug; LOE, level of evidence; SOR, strength of recommendation; A, appropriateness; RA, rheumatoid arthritis; csDMARD, conventional synthetic disease modifying antirheumatic drug; AS, ankylosing spondylitis; NSAID, nonsteroidal anti-inflammatory drug; TNF, tumor necrosis factor; IL-17, interleukin-17; MTX, methotrexate.

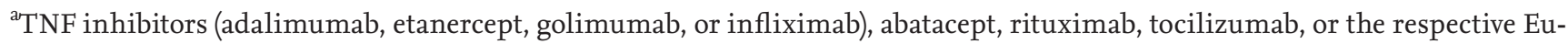
ropean Medicines Agency (EMA)-approved/Food and Drug Administration (FDA)-approved biosimilars for the patients with RA; TNF inhibitors (adalimumab, etanercept, golimumab, infliximab, or the respective EMA-approved/FDA-approved biosimilars) or IL-17 inhibitors for the patients with AS.

${ }^{\mathrm{b}}$ Appropriateness was evaluated according to RAND/University of California Los Angeles (ULCA) appropriateness method; appropriate (A) was defined as median score ranged 7-9 without disagreement.

${ }^{\mathrm{c}}$ Level of agreement was evaluated according to 9-point Likert scale; high agreement was defined as agreement scored between 7 and 9.

${ }^{\mathrm{d}}$ Positivity of rheumatoid factor or anti-citrullinated protein antibodies, joint damage, high disease activity, failure of $\geq 2 \mathrm{csD}$ MARDs. 
practice setting

This clinical consensus statement covered all currently available bDMARDs in Korea: anti-tumor necrosis factor (TNF) inhibitors including infliximab, etanercept, adalimumab, and golimumab, and anti-B-cell agent (rituximab), co-stimulation inhibitor (abatacept), and interleukin 6 (IL-6) receptor blocker (tocilizumab) for treatment of RA; TNF inhibitors and IL-17 inhibitor (secukinumab) for treatment of AS, and European Medicines Agency (EMA), Food and Drug Administration (FDA) or Ministry of Food and Drug Safety-approved biosimilar DMARDs (bsDMARDs). The targeted synthetic DMARDs (tsDMARDs) were not discussed here. The improvement of the quality of care included both efficacy and safety of bDMARDs.

\section{Literature search}

We searched the existing literature for systematic review, clinical consensus statement, recommendations, and clinical practice guidelines. Literature search was performed under the following principles: (1) guidelines should be developed by the international network or the national association of rheumatology; (2) guidelines should be published after 2015; and (3) guidelines should be written in English or Korean. Following the review, six guidelines were selected for the management of RA and AS $[9,10,12,17,18,25,26]$. The Korean guidelines for tuberculosis (TB) and hepatitis B virus (HBV) infection, published by the Korean Academy of Tuberculosis and Respiratory Diseases (KATRD) and the Korean Association for the Study of the Liver, respectively, were also included in the development of the clinical consensus statement $[27,28]$.

Because the evidence supporting the guidelines is rapidly evolving, further literature search was performed to confirm the currency of recommendations. The working group selected the relevant evidence and evaluated the current evidence. Based on these processes, the consensus statement was updated.

\section{Development of statements}

To evaluate the quality of evidence, we used the GRADE system (Table 1) [19,20]. The evidence from the reference studies was reviewed by the working group to grade the quality of evidence. The strength of recommendations was determined based on the estimated effect, overall quality of evidence, values and preference, and resource use [29].

\section{Agreement of statement}

The members of the consensus group voted for the appropriateness of 12 statements. The survey was performed with Internet-based software according to the modified Delphi technique. The members rated their agreement of 12 statements on a 9-point Likert scale (1: strongly disagree; 3: disagree; 5: neutral; 7: agree; 9: strongly agree). The median score of $\geq 7.0$ on a 9-point Likert scale was considered appropriate for consensus statement [30]. As with the ballot, different opinions were also collected.

Following the initial Delphi round, the consensus statement was modified based on the expert opinion from the consensus group. The modified statement was confirmed through another Delphi round.

\section{Approval of clinical consensus statement}

The draft statement was approved by all members of the consensus group and the development group. The draft of 12 consensus statements was presented on the 2018 KCR Annual Scientific Meeting, and feedback from the target users was used to finalize the clinical consensus statement. The final manuscript was officially endorsed by KCR. The final version of clinical consensus statement was released on web-site of KCR at 2019 (www. rheum.or.kr).

\section{EXPERT OPINION FOR THE MANAGEMENT OF INFLAMMATORY ARTHRITIS IN ADULTS WITH bDMARDS IN SOUTH KOREA}

\section{General principle of bDMARDs treatment}

1. bDMARDs should be prescribed by an expert experienced in the diagnosing and managing rheumatic diseases, who can monitor disease activity using standardized assessment tools, and perform safety monitoring (level of evidence [LOE]: low; strength of recommendation [SOR]: strongly recommended).

This statement indicates the importance of an expert care in the treatment of rheumatic diseases, in particu- 
lar, with bDMARDs. The care by an expert in rheumatic diseases, such as a rheumatologist, should be seriously considered and emphasized, because it allows the severity of disease to be estimated, a plan of care to be developed and initiated, and the patient's response to the treatment to be assessed properly [12,31]. In addition, the management with bDMARDs may lead to various adverse events which include injection site reactions, infusion reactions, exacerbation of heart failure, cytopenia, infections including lethal TB and fungal infections, demyelinating diseases, increased risk of cancer, anaphylaxis and even death [15,32-37]. Thus, meticulous monitoring by an expert for any new or developing conditions is essential to minimize the potential of harm caused by these agents $[10,18,38,39]$.

In this regard, this statement emphasizes that the treating physician should have extensive knowledge of the entire rheumatic disease spectrum and is capable of providing comprehensive management, taking into account not only efficacy but also risks associated with the therapy. The expert panel reached 100\% of agreement and strongly recommended this statement pertaining to the qualification of an expert for use of bDMARDs.

2. Patients should be provided with education about their treatment with bDMARDs (LOE: moderate; SOR: strongly recommended).

To standardize the management of inflammatory arthritis including RA and AS, clinical practice guidelines and recommendations have been published in many countries [7,9-13,18]. Many of these emphasize that patient education is as important as pharmacological and non-pharmacological treatment because patients play a central role in managing their disease. Patients' awareness about their diseases and management can promote long-term treatment adherence [7]. Therefore, it is crucial to communicate with patients by giving relevant information and education about their disease, its management, risks, and coping skills. In addition, clinicians should provide information tailored to meet the needs of each patient at different stages of their disease and associated comorbidities [40].

Thus, the expert panel reached 100\% agreement and strongly recommended that patients should be provided with education about their treatment with bDMARD.

\section{Indications for initiation of bDMARDs in patients with RA and AS}

3. In RA, if the treatment target is not achieved with
the first conventional synthetic DMARDs (csD-
MARDs) strategy, when poor prognostic factors are
present, addition of a bDMARD should be consid-
ered (LOE: moderate; SOR: strongly recommended).

The csDMARDs in this expert opinion include methotrexate (MTX), leflunomide (LEF), sulfasalazine (SSZ), and hydroxychloroquine (HCQ). It does not include tsDMARDs, namely the Janus kinase inhibitors (Jak-inhibitors) such as tofacitinib or baricitinib. All bDMARDs mentioned in this expert opinion were bDMARDs currently approved for management of RA. Currently approved bDMARDs for use in Korea are TNF inhibitors (adalimumab, etanercept, golimumab, and infliximab); a co-stimulation inhibitor (abatacept); an IL-6 receptor blocker (tocilizumab); an anti-B-cell agent (rituximab); an IL-17 inhibitor (secukinumab), and EMA, FDA or Ministry of Food and Drug Safety-approved bsDMARDs.

All bDMARDs approved for treatment of RA had showed efficacy in RA patients with inadequate response to MTX (MTX-IR). ACR response at 24 weeks after addition of bDMARDs in MTX-IR patients was significantly superior to those treated with MTX plus placebo [41-55]. Remission rate at 6 months after addition for adalimum$\mathrm{ab}$ [48], abatacept [56], and rituximab [41] in patient with RA that had remained active despite MTX treatment was significantly higher compared to that in patients with placebo pulse MTX. Remission rates at 12 months in MTX-IR RA patients with abatacept [56,57] and tocilizumab [58] were superior to that in MTX-IR RA patients with placebo. In addition, radiographic progression at 12 months in patients with RA who remained active despite of MTX treatment was halted when they received bDMARDs $[46,48,57-59]$. ACR response at 6 months of etanercept [60], adalimumab [51], and tocilizumab [61], and ACR response at 12 months of etanercept were superior to that of placebo in RA patients with active disease despite of csDMARDs other than MTX [62].

The bDMARDs including biologic originator DMARDs (boDMARDs) and bsDMARDs are recommended without specific preference in RA patients who have IR according to a validated composite measure, or 
intolerance to csDMARDs. There is no difference in efficacy and safety, irrespective of their target, among the bDMARDs in head-to-head trials, meta-analysis, or the results of the systemic literature reviews [11,14-16,63-65].

Rituximab was approved for use in RA patients who failed to TNF inhibitors although it is effective in $\mathrm{bD}$ MARDs-naïve RA patients. Rituximab was significantly effective and well tolerated when combined with MTX therapy in RA patients IR to MTX compared with placebo in ACR20, ACR50, ACR7o response, and the Health Assessment Questionnaire score at 24 weeks [66]. Initial treatment with rituximab was non-inferior to initial TNF inhibitor treatment in randomized controlled trial (RCT) in patients with seropositive RA who were naïve to treatment with bDMARDs [67]. Of note, it is frequently used for RA patients IR to csDMARDs, in particular when the patients have specific contraindications to other bDMARDs such as lymphoma, or demyelinating disorder [47,68].

Some factors indicating moderate to high disease activity according to composite measures after csDMARDs therapy [69] such as the presence of rheumatoid factor and/or anti-citrullinated protein antibodies $[60,70]$, presence of early erosion [6o], high swollen joint counts $[60,71,72]$ or high acute phase reactant level $[60,72]$ were proven to be associated with poor disease outcome in patients with RA. In addition, a further csDMARDs may have only minimal impact if RA patients have failed to respond to two or more csDMARDs [73,74]; therefore, EULAR recommendation included failure to two or more csDMARDs as a poor prognostic factor [12].

This statement received $100 \%$ agreement by the expert panel's vote and is strongly recommended despite moderate evidence.

4. In AS, bDMARDs should be considered in patients with persistently high disease activity despite conventional treatments including nonsteroidal anti-inflammatory drugs (NSAIDs); current practice is to start with TNF inhibitors therapy (LOE: high for TNF inhibitors, moderate for IL-17 inhibitors; SOR: strongly recommended).

Conventional treatment in AS includes not only NSAIDs but also non-pharmacological management, a local glucocorticoid injection in patients with peripheral symptoms, and a treatment with SSZ in case of periph- eral arthritis [18]. In most patients with symptomatic AS, however, initial therapy with NSAIDs alone is generally recommended $[10,18,38,75,76]$. This recommendation based on the evidence of the Assessment in Ankylosing Spondylitis response criteria (ASAS) 20 response of $>$ $70 \%$, an ASAS40 response in $>50 \%$ of the patients starting with an NSAIDs in early disease or $35 \%$ of patients in ASAS partial remission $[18,75]$. It was also reported that approximately $70 \%$ to $80 \%$ of AS patients experienced substantial relief of their symptoms, including back pain and stiffness, with NSAIDs [76].

An IR to NSAIDs typically requires trials with at least two NSAIDs that have been taken in an adequate dose for at least 2 to 4 weeks each [10]. Current prevailing opinion for the management of AS patients with persistent high disease activity despite the initial NSAIDs therapy is to start with bDMARDs, especially TNF inhibitors $[10,18,77-79]$. Due to the concern of high cost and social burden, the use of a biologic agent for active AS is particularly appropriate for those with high or very high disease activity, although they are effective in patients with mild to moderate symptoms as well. High disease activity can be defined as a Bath Ankylosing Spondylitis Disease Activity Index (BASDAI) $\geq 4.0$ or Ankylosing Spondylitis Disease Activity Score (ASDAS) $\geq 2.1$ [18]. Any of the TNF inhibitors is an acceptable option. The choice between them is based upon patient preferences, physician preference and experience, national regulatory and cost issues, and possible coexisting conditions such as inflammatory bowel diseases (IBD) or uveitis. TNF monoclonal antibodies such as adalimumab and infliximab are preferred over etanercept for the treatment of AS, IBD, and recurrent uveitis associated with AS [8o-83]. An IL-17 inhibitor (secukinumab) is known to increase risk of the new onset or exacerbation of IBD in several studies; therefore, comorbidities and risk factors should be considered when selecting bDMARDs in active AS patients $[84,85]$. Substantial evidences of consistent improvements and effective clinical outcomes of TNF inhibitors in active AS patients is sufficient to support this clinical practice [10,18,38,77-79].

Secukinumab is a reasonable alternative to TNF inhibitors, with a similar level of efficacy $[18,86,87]$. Several clinical trials demonstrates that another IL-17 inhibitor, ixekizumab, which is available commercially for the treatment of psoriasis and psoriatic arthritis, significantly improved the signs and symptoms after 16 weeks 
in active AS patients who are bDMARDs-naïve, and have IR to or intolerance of TNF inhibitors [88,89]. However, studies there is much more experience in clinical practice with TNF inhibitors than with IL-17 inhibitor [18].

For these reasons, the expert panel voted $100 \%$ of agreement for starting bDMARDs, particularly TNF inhibitors as first bDMARDs and IL-17 inhibitor as an alternative option, in AS patients with IR to conventional treatment, and strongly recommended.

\section{Concomitant use of csDMARDs with bDMARDs in RA or AS patients}

5. In RA, bDMARDs should be combined with a csD-
MARDs such as MTX (LOE: high; SOR: strongly rec-
ommended).

All bDMARDs is more efficacious when combined with MTX than as monotherapy in patients with RA $[14,49,62,90-92]$. The combination of bDMARDs such as etanercept [62] or adalimumab [90] with MTX, was significantly better in reduction of disease activity, retardation of radiographic progression, and achieving clinical remission compared with MTX or bDMARDs alone. Extended studies also supported this results that etanercept [93] and adalimumab in combination with MTX [94] was superior to either bDAMRDs alone in improving remission rate and inhibiting radiographic progression in patients with RA. Tocilizumab in combination with MTX in patients with early RA [95] and MTX-IR RA [96-98], conveyed better clinical efficacy and showed prevention of radiographic progression than tocilizumab alone. MTX can be used at 7.5 to $10 \mathrm{mg}$ per week when combined with bDMARD to provide efficacy while minimizing intolerance leading to discontinuation [99,100].

Furthermore, the use of MTX as concomitant drug with bDMARDs reduces the incidence of antidrug antibody which results in secondary treatment failure in patients with RA receiving bDMARDs [99,100]. However, EULAR recommendation for management RA, updated 2016, did not recommend routine testing of antidrug antibodies and drug level because a positive clinical response would not lead to cessation of therapy even in the presence of antidrug antibodies, or low drug levels [12].

Several studies demonstrated that combination of
csDMARDs, other than MTX, with bDMARDs can also be effective in patients with RA. Combination of TNF inhibitors with LEF showed comparative effectiveness to those with MTX in patients with RA [101]. In an another study, RA patients receiving adalimumab and concomitant csDMARDs (regardless of type or number of DMARDs such as HCQ, SSZ, MTX, or LEF) showed greater improvement in most of the outcome measures than patients receiving adalimumab alone [102].

For all of the above, the expert panel reached 100\% agreement and strongly recommended that bDMARDs should be combined with a csDMARD such as MTX in patients with RA unless intolerant or have contraindication to csDMARDs.

6. In AS, bDMARD monotherapy without csDMARDs is recommended patients with purely axial disease (LOE: high; SOR: strongly recommended).

This statement indicated that the combination therapy with csDMARDs is not supported by the evidence in AS patients with exclusively axial involvement on bDMARDs. Based on the Cochrane reviews and existing recommendations, there was no strong evidence of support for using csDMARDs including SSZ, MTX, and LEF in patients with purely axial disease [18,39]. SSZ only, however, could be considered as a treatment option in patients with peripheral arthritis $[10,18]$. In addition, concomitant use of csDMARDs, such as MTX, is not recommended as most of the limited evidence indicates that this provides no additional benefit in patients with AS [18,103,104].

The expert panel agreed $93.8 \%$ in vote and strongly recommended using bDMARDs monotherapy without csDMARDs in patients with purely axial disease.

\section{Treatment options after failure of or intolerance to first bDMARDs in RA or AS patients}

7. In RA, if a bDMARD has failed, switching to another bDMARD should be considered (LOE: high; SOR: strongly recommended).

In a treat-to-target strategy of RA, if a patient did not achieve adequate response with the first bDMARD, switching to another bDMARD should be instituted 
without a significant delay. The EULAR recommendation did not prioritize any specific bDMARDs after failure in first bDMARDs in patients with RA [12]. The EULAR recommendation state that any bDMARDs including another TNF inhibitors, could be used in RA patients whom failed TNF inhibitors, which indicates that any bDMARDs with the same or with another mode of action are recommended in case with failure to bDMARDs in RA. This was based on the data from meta-analysis, systematic literature reviews, and prospective studies $[14,15,105]$. One prospective study showed that abatacept, rituximab, and different TNF inhibitor demonstrated similar effect in patients with RA who had failed TNF inhibitor [106]. Rituximab use as second-line therapy in RA patients after TNF inhibitor failure led to improvements in the efficacy and functional variables at 6 months, with no serious adverse events [107]. Even primary non-responders to a TNF inhibitor were shown to have some response to another TNF inhibitor in several studies [108-112].

There is one RCT showed that a non-TNF inhibitor was more effective than the 2nd TNF inhibitor in RA patient with primary failure to the first TNF inhibitor [113] and also lack studies investing the effect of TNF inhibitors as second-line bDMARDs after failure to $\mathrm{bD}$ MARDs with other modes of action in patients with RA. Therefore, the choice should be based on a shared decision between the patient and the physician based on patient's characteristics and preferences. The EULAR recommendation also stated that bsDMARD of any of the reference boDMARDs should not be considered in patients who have IR or failed to the respective boDMARD (or another bsDMARD of the same molecule) or vice versa [12].

Expert panel voted 100\% of agreement for this part based on the above evidence and strongly recommended that switching to another bDMARDs should be considered if the first bMDARD has failed in patients with RA.

8. In AS, if the treatment with the first TNF inhibitor has failed, switching to another TNF ihibitors or IL-17 inhibitor should be considered (LOE: low for TNF inhibitor/moderate for IL-17 inhibitor; SOR: weakly recommended for TNF inhibitors, strongly recommended for IL-17 inhibitor).
Treatment options in patients with AS who have responded inadequately to the first TNF inhibitor are another TNF inhibitors or an IL-17 inhibitor such as secukinumab $[18,114,115]$. For primary failure to an initial TNF inhibitor, either the second TNF inhibitors or secukinumab could be considered. However, given the different mechanism of action, anti-IL-17 inhibitor is preferred as more reasonable option $[18,115]$. In patients with secondary failure, the treatment with another TNF inhibitor should be considered $[18,114,115]$. In general, the response rate of a second TNF inhibitors decreases compared with the first. However, the data showed good responses to subsequent TNF inhibitors in AS [116,117]. IL-17 inhibitor has also proven efficacy in patients who had failed a TNF inhibitor but this was also less than in TNF inhibitor-naïve patients $[85,86]$.

Expert panel agreed $100 \%$ in vote for this statement, and weakly recommended a TNF inhibitor and strongly recommended an anti-IL17 inhibitor as 2nd bDMARDs in patients with failure to first TNF inhibitor.

\section{Monitoring strategies before or during use of bM- DARDs in patients with RA or AS}

9. Prior to initiating bDMARDs, disease activity, joint damage, functional capacity, extra-articular manifestations, comorbidities, vaccination history, and pregnancy status should be assessed in all patients with inflammatory arthritis (LOE: low; SOR: strongly recommended).

Disease activity is the fundamental criteria to determine the use of biologic agents in inflammatory arthritis, based on the treat-to-target strategy [118,119]. All of the current guidelines recommend that the disease activity and disease-related features should be evaluated in patients with inflammatory arthritis prior to initiating biologic therapy.

Although biologic therapy is proven to improve the clinical outcomes in patients with IR to conventional therapy, the use of bDMARD in patients with comorbid conditions requires special caution. Several safety data regarding bDMARDs have been published [120-122]. Thereafter, the 2015 ACR and APLAR recommendations, and 2018 National Institute for Health and Care Excellence (NICE) guidelines included the management of 
RA in special clinical situations, such as congestive heart failure [35,123], combined hepatitis viral infection (described in detail in statement 11), past history of malignancy [124-126], and previous severe infections [127-129]. However, at the current time, the recommendations are still based on evidences of low-quality.

RA patients have an increased risk of infection when compared to the general population [130]. In addition, use of biologic therapy such as TNF inhibitor further increases the risk of infection [131,132]. Given the high risk of infection in patients receiving biologic therapy, the 2015 ACR and APLAR guidelines recommended assessment of vaccination history and completion of outstanding vaccination when possible, before initiating bDMARDs. Several RCTs studied the safety and efficacy of pneumococcus, influenza, and HBV vaccination in patients receiving biologic therapy [133-140]. Biologic therapy seems to be unrelated to the side effect of the killed vaccine. However, due to the theoretical risk and the limited data, the live vaccine is contraindicated during the bDMARDs therapy.

The safety of bDMARD during pregnancy was evaluated in several observation cohort studies [141]. TNF inhibitors, especially adalimumab and etanercept, showed no significant difference in miscarriage and congenital malformation compared with disease-matched controls [142-153]. Other biologic therapies still have limited safety data. Based on the currently available data, physicians can discuss the use of biologic therapy with patients during pregnancy, if the disease activity is not otherwise controlled.

Given the importance of the safety issue of bDMARDs, assessment of comorbidities, vaccination history, and pregnancy status should be emphasized in all patients receiving biologic therapy, despite of insufficient evidence.

\footnotetext{
10. All patients should be screened for active or latent tuberculosis before starting bDMARDs, and if tuberculosis is detected, patients should receive adequate anti-tuberculosis treatment, appropriately (LOE: low; SOR: strongly recommended).
}

TB is an important complication following biologic therapies in patients with inflammatory diseases. The use of TNF inhibitors increases the risk of TB, especially in patients with latent TB infection $[154,155]$. South Korea is a country of intermediate TB burden. The annual incidence of TB is 55 per 100,000 persons in 2017 [156], and the estimated prevalence of latent TB is $33 \%$, which is higher than those in other developed western countries [157]. The nationwide study conducted in Korea between 2005 and 2009 showed the significantly higher incidence of TB in patients who treated with TNF inhibitors, which was 1,017 per 100,000 person-years [158]. Based on the clear association between TB and TNF inhibitors, the panels strongly recommend that all patients should be screened for active or latent TB before initiating biologic therapy, and patients with active or latent TB infection should receive appropriate anti-TB therapy.

Studies have suggested that patients treated with monoclonal antibody, such as infliximab and adalimumab, had a higher risk of TB than patients treated with etanercept [158-160]. The effect of biologic therapies other than TNF inhibitors on risk of TB is largely unknown. Although data from clinical trials and national registries suggested that non-anti-TNF targeted biologics were not associated with the increased TB risk, further research would be required to reach a definite conclusion [161]. Based on the currently available data, the 2015 APLAR guideline recommended that patients with a history of TB or latent TB are preferentially treated with other biologic therapies than monoclonal antibody TNF inhibitors.

Diagnosis and treatment of latent TB can be referred to country-specific guidelines [25]. The 2017 KAT'RD guideline recommend that interferon-gamma releasing assay can be used alone or in combination with tuberculin skin test for diagnosis of latent TB, and biologic therapy can be started 3 weeks after latent TB treatment $[27,28]$.

11. All patients should be screened for hepatitis B virus
infection before starting bDMARDs, and if hepatitis
B virus infection is identified, proper antiviral thera-
py should be considered (LOE: high for screening/low
for antiviral therapy; SOR: strongly recommended).

Korea is classified into the high-prevalent region of chronic HBV infection. Although the national health program has substantially reduced the prevalence of 
HBV infection, the positivity rate of HBV surface antigen (HBsAg) was still $3.4 \%$ for males and $2.6 \%$ for females in 2012 [162].

Several studies have shown that treatment with rituximab and TNF inhibitors increased the risk of reactivation of HBV [163-167]. The rate of HBV reactivation was reported to be $12.3 \%$ to $39 \%$ among HBsAg (+) patients receiving TNF inhibitors. Although the association between HBV and rituximab is unclear in patients with rheumatic diseases, the reactivation rate of HBV infection in lymphoma patients receiving rituximab-containing regimen was reported to be $24 \%$ to $67 \%$. The rate of $\mathrm{HBV}$ reactivation in patients with resolved $\mathrm{HBV}$ infection (HBsAg (-)/anti-HBV core antibody (+)) also increased following the treatment with rituximab and TNF inhibitors $[164,166,168]$. The effect of other bDMARDs on HBV reactivation is largely unknown. However, the panels recommend that all patients receiving biologic therapy should be screened for HBV infection, given the increased risk of $\mathrm{HBV}$ reactivation in RA patients, regardless of biologic therapy [169].

The 2015 ACR, APLAR, and 2018 NICE guideline consistently emphasize the importance of screening of HBV infection prior to biologic therapy and antiviral treatment during biologic therapy. Preventive antiviral therapy significantly reduced the risk of $\mathrm{HBV}$ reactivation in HBsAg (+) lymphoma patients receiving rituximab-containing chemotherapy [170-172] and HBsAg (+) RA patients treated with TNF inhibitors [163]. Thus, based on the currently available evidence, the panels recommend that screening for HBV infection should be performed prior to biologic therapy, and preventive antiviral therapy should be considered in patients receiving biologic therapy.

12. All patients receiving bDMARDs should be monitored for disease activity, joint damage, functional capacity, extra-articular manifestations, comorbidities, and drug side effect and toxicity (LOE: low; SOR: strongly recommended).

Based on the treat-to-target strategy, the monitoring of disease activity is important to guide the treatment in inflammatory arthritis [118,119]. The 2015 ACR, APLAR guidelines, and 2016 EULAR guideline, suggested that disease activity of RA should be monitored every 1 to 3 months in active disease, and at least 3 to 6 months in stable disease $[9,12,25]$. The 2016 ASAS-EULAR guideline recommended assessment of disease activity of axial spondyloarthritis on individual basis [18]. Even though composite measures of disease activity indicate inactive disease, joint damage should be evaluated in patients with inflammatory arthritis. Radiographic progression does not necessarily correlate with the disease activity [173].

In addition, the voting panels agreed to evaluate the functional capacity and extra-articular manifestations during biologic therapy. Biologic therapy may affect the functional capacity, and extra-articular manifestation in patients with inflammatory arthritis. Likewise, these clinical features may affect the choice of certain bDMARDs.

As mentioned previously, bDMARD should be cautiously prescribed in special clinical situations, including combined infection, congestive heart failure, past history of malignancy, and pregnancy. Of note, the use of bDMARDs was associated with the increased risk of certain infections, including TB and HBV. Safety concern about malignancy is one of the major issues in patients receiving bDMARDs treatment and further prospective observational registry is needed. One study showed that cancer incidence was similar in RA patients treated with TNF inhibitors and csDMARDs, which suggested that TNF inhibitors may be a safe therapeutic option for RA treatment, in terms of malignancy [174]. Furthermore, biologic therapy is associated with various drug-related toxicities [175]. Therefore, the all patients receiving biologic therapy should be monitored for therapy-related toxicities based on the currently available evidence.

\section{CONCLUSIONS}

This Korean expert consensus for the use of bDMARDs in inflammatory arthritis developed by the KCR provides physicians participating in the care of inflammatory arthritis with a guidance stemming from upto-date best evidence based on Korean health care situations. It is critical for physicians to understand the evidence-based use of bDMARDs to choose the optimal agents and to protect the patients from the harmful effects of the drug, which in turn can contribute to a bet- 
ter management of inflammatory arthritis in everyday practice. In addition, patients can benefit from receiving the appropriate treatment, according to the verified guidelines, for the effective management of their disease and improved quality of life. Furthermore, this expert opinion emphasizes the role of education for patients being treated with bDMARDs in inflammatory arthritis, as patient's awareness and knowledge about the course of diseases, medications, treatment goal, and prognosis improves compliance and successful outcome $[7,41,176]$. This expert consensus may contribute to the promotion of the standard of care in Korea for the management of inflammatory arthritis with bDMARDs, until the final development of validated guidelines on this important management issue can be realized.

\section{Conflict of interest}

No potential conflict of interest relevant to this article was reported.

\section{Acknowledgments}

The Task Force gratefully acknowledges the contribution of the consensus group members for participating in the agreement process of the statements and for generously sharing their expert opinions. We would also like to acknowledge KCR Executive Committee for the endorsement of the Expert Consensus.

\section{REFERENCES}

1. Pincus T, Callahan LF, Sale WG, Brooks AL, Payne LE, Vaughn WK. Severe functional declines, work disability, and increased mortality in seventy-five rheumatoid arthritis patients studied over nine years. Arthritis Rheum 1984;27:864-872.

2. Solomon DH, Karlson EW, Rimm EB, et al. Cardiovascular morbidity and mortality in women diagnosed with rheumatoid arthritis. Circulation 2003;107:1303-1307.

3. Helmick CG, Felson DT, Lawrence RC, et al. Estimates of the prevalence of arthritis and other rheumatic conditions in the United States. Part I. Arthritis Rheum 2008;58:15-25.

4. Salaffi F, Sarzi-Puttini P, Girolimetti R, Atzeni F, Gasparini S, Grassi W. Health-related quality of life in fibromyalgia patients: a comparison with rheumatoid arthritis pa- tients and the general population using the SF-36 health survey. Clin Exp Rheumatol 2009;27:S67-S74.

5. Dougados M, Baeten D. Spondyloarthritis. Lancet 2011;377:2127-2137.

6. Stolwijk C, van Tubergen A, Castillo-Ortiz JD, Boonen A. Prevalence of extra-articular manifestations in patients with ankylosing spondylitis: a systematic review and meta-analysis. Ann Rheum Dis 2015;74:65-73.

7. Luqmani R, Hennell S, Estrach C, et al. British Society for Rheumatology and British Health Professionals in Rheumatology guideline for the management of rheumatoid arthritis (after the first 2 years). Rheumatology (Oxford) 2009;48:436-439.

8. Corbett M, Soares M, Jhuti G, et al. Tumour necrosis factor- $\alpha$ inhibitors for ankylosing spondylitis and non-radiographic axial spondyloarthritis: a systematic review and economic evaluation. Health Technol Assess 2016;20:1-334.

9. Singh JA, Saag KG, Bridges SL Jr, et al. 2015 American College of Rheumatology guideline for the treatment of rheumatoid arthritis. Arthritis Rheumatol 2016;68:1-26.

10. Ward MM, Deodhar A, Akl EA, et al. American College of Rheumatology/Spondylitis Association of America/Spondyloarthritis Research and Treatment Network 2015 recommendations for the treatment of ankylosing spondylitis and nonradiographic axial spondyloarthritis. Arthritis Rheumatol 2016;68:282-298.

11. Hamilton L, Barkham N, Bhalla A, et al. BSR and BHPR guideline for the treatment of axial spondyloarthritis (including ankylosing spondylitis) with biologics. Rheumatology (Oxford) 2017;56:313-316.

12. Smolen JS, Landewe R, Bijlsma J, et al. EULAR recommendations for the management of rheumatoid arthritis with synthetic and biological disease-modifying antirheumatic drugs: 2016 update. Ann Rheum Dis 2017;76:960-977.

13. Lau CS, Chia F, Dans L, et al. 2018 Update of the APLAR recommendations for treatment of rheumatoid arthritis. Int J Rheum Dis 2019;22:357-375.

14. Nam JL, Takase-Minegishi K, Ramiro S, et al. Efficacy of biological disease-modifying antirheumatic drugs: a systematic literature review informing the 2016 update of the EULAR recommendations for the management of rheumatoid arthritis. Ann Rheum Dis 2017;76:1113-1136.

15. Ramiro S, Sepriano A, Chatzidionysiou K, et al. Safety of synthetic and biological DMARDs: a systematic literature 
review informing the 2016 update of the EULAR recommendations for management of rheumatoid arthritis. Ann Rheum Dis 2017;76:1101-1136.

16. Yoo DH, Prodanovic N, Jaworski J, et al. Efficacy and safety of CT-P13 (biosimilar infliximab) in patients with rheumatoid arthritis: comparison between switching from reference infliximab to CT-P13 and continuing CT$\mathrm{P}_{13}$ in the PLANETRA extension study. Ann Rheum Dis 2017;76:355-363.

17. Holroyd CR, Seth R, Bukhari M, et al. The British Society for Rheumatology biologic DMARD safety guidelines in inflammatory arthritis: executive summary. Rheumatology (Oxford) 2019;58:220-226.

18. van der Heijde D, Ramiro S, Landewe R, et al. 2016 Update of the ASAS-EULAR management recommendations for axial spondyloarthritis. Ann Rheum Dis 2017;76:978-991.

19. Guyatt GH, Oxman AD, Kunz R, et al. Going from evidence to recommendations. BMJ 2008;336:1049-1051.

20. Meerpohl JJ, Langer G, Perleth M, Gartlehner G, Kaminski-Hartenthaler A, Schunemann H. GRADE guidelines: 3. Rating the quality of evidence (confidence in the estimates of effect). Z Evid Fortbild Qual Gesundhwes 2012;106:449-456.

21. Arnett FC, Edworthy SM, Bloch DA, et al. The American Rheumatism Association 1987 revised criteria for the classification of rheumatoid arthritis. Arthritis Rheum 1988;31:315-324.

22. Aletaha D, Neogi T, Silman AJ, et al. 2010 Rheumatoid arthritis classification criteria: an American College of Rheumatology/European League Against Rheumatism collaborative initiative. Arthritis Rheum 2010;62:2569-2581.

23. van der Linden S, Valkenburg HA, Cats A. Evaluation of diagnostic criteria for ankylosing spondylitis: a proposal for modification of the New York criteria. Arthritis Rheum 1984;27:361-368.

24. Rudwaleit M, van der Heijde D, Landewe R, et al. The development of Assessment of SpondyloArthritis International Society classification criteria for axial spondyloarthritis (part II): validation and final selection. Ann Rheum Dis 2009;68:777-783.

25. Lau CS, Chia F, Harrison A, et al. APLAR rheumatoid arthritis treatment recommendations. Int J Rheum Dis 2015;18:685-713.

26. Allen A, Carville S, McKenna F; Guideline Development Group. Diagnosis and management of rheumatoid arthritis in adults: summary of updated NICE guidance.
BMJ 2018;362:k3015.

27. The Korean Academy of Tuberculosis and Respiratory Diseases. Korean guidelines for tuberculosis [Internet]. Seoul (KR): The Korean Academy of Tuberculosis and Respiratory Diseases, 2017 [cited 2019 Dec 24]. Available from: https://www.lungkorea.org/bbs/index. $\mathrm{html}$ ? code=guide \&category=\&gubun=\&page=1\&number $=7563 \&$ mode=view\&keyfield=\&key=.

28. Korean Association for the Study of the Liver. KASL clinical practice guidelines: management of chronic hepatitis B. Clin Mol Hepatol 2016;22:18-75.

29. Andrews JC, Schunemann HJ, Oxman AD, et al. GRADE guidelines: 15. Going from evidence to recommendation-determinants of a recommendation's direction and strength. J Clin Epidemiol 2013;66:726-735.

30. Fitch K, Bernstein SJ, Aguilar MD, et al. The RAND/UCLA appropriateness method user's manual [Internet]. Santa Monica (CA): RAND Corp., c2001 [cited 2019 Dec 24]. Available from: https://www.rand.org/content/dam/rand/ pubs/monograph_reports/2011/MR1269.pdf.

31. Huizinga TW, Pincus T. In the clinic. Rheumatoid arthritis. Ann Intern Med 2010;153:ITC1-1-ITC1-15.

32. The Lenercept Multiple Sclerosis Study Group and The University of British Columbia MS/MRI Analysis Group. TNF neutralization in MS: results of a randomized, placebo-controlled multicenter study. Neurology 1999;53:457-465.

33. Anker SD, Coats AJ. How to recover from renaissance? The significance of the results of RECOVER, RENAISSANCE, RENEWAL and ATTACH. Int J Cardiol 2002;86:123-130.

34. Hastings R, Ding T, Butt $\mathrm{S}$, et al. Neutropenia in patients receiving anti-tumor necrosis factor therapy. Arthritis Care Res (Hoboken) 2010;62:764-769.

35. Mann DL, McMurray JJ, Packer M, et al. Targeted anticytokine therapy in patients with chronic heart failure: results of the Randomized Etanercept Worldwide Evaluation (RENEWAL). Circulation 2004;109:1594-1602.

36. Mocci G, Marzo M, Papa A, Armuzzi A, Guidi L. Dermatological adverse reactions during anti-TNF treatments: focus on inflammatory bowel disease. J Crohns Colitis 2013;7:769-779.

37. van Oosten BW, Barkhof F, Truyen L, et al. Increased MRI activity and immune activation in two multiple sclerosis patients treated with the monoclonal anti-tumor necrosis factor antibody cA2. Neurology 1996;47:1531-1534.

38. van der Heijde D, Sieper J, Maksymowych WP, et al. 2010 Update of the International ASAS recommendations for 
the use of anti-TNF agents in patients with axial spondyloarthritis. Ann Rheum Dis 2011;70:905-908.

39. Braun J, van den Berg R, Baraliakos X, et al. 2010 Update of the ASAS/EULAR recommendations for the management of ankylosing spondylitis. Ann Rheum Dis 2011;70:896-904.

40. Stoffer MA, Smolen JS, Woolf A, et al. Development of patient-centred standards of care for rheumatoid arthritis in Europe: the eumusc.net project. Ann Rheum Dis 2014;73:902-905.

41. Emery P, Deodhar A, Rigby WF, et al. Efficacy and safety of different doses and retreatment of rituximab: a randomised, placebo-controlled trial in patients who are biological naive with active rheumatoid arthritis and an inadequate response to methotrexate (Study Evaluating Rituximab's Efficacy in MTX iNadequate rEsponders (SERENE)). Ann Rheum Dis 2010;69:1629-1635.

42. Smolen J, Landewe RB, Mease P, et al. Efficacy and safety of certolizumab pegol plus methotrexate in active rheumatoid arthritis: the RAPID 2 study: a randomised controlled trial. Ann Rheum Dis 2009;68:797-804.

43. Keystone EC, Genovese MC, Klareskog L, et al. Golimumab, a human antibody to tumour necrosis factor \{alpha\} given by monthly subcutaneous injections, in active rheumatoid arthritis despite methotrexate therapy: the GO-FORWARD Study. Ann Rheum Dis 2009;68:789-796.

44. Smolen JS, Beaulieu A, Rubbert-Roth A, et al. Effect of interleukin-6 receptor inhibition with tocilizumab in patients with rheumatoid arthritis (OPTION study): a double-blind, placebo-controlled, randomised trial. Lancet 2008;371:987-997.

45. Schiff M, Keiserman M, Codding C, et al. Efficacy and safety of abatacept or infliximab vs placebo in ATTEST: a phase III, multi-centre, randomised, double-blind, placebo-controlled study in patients with rheumatoid arthritis and an inadequate response to methotrexate. Ann Rheum Dis 2008;67:1096-1103.

46. Keystone E, Heijde Dv, Mason D Jr, et al. Certolizumab pegol plus methotrexate is significantly more effective than placebo plus methotrexate in active rheumatoid arthritis: findings of a fifty-two-week, phase III, multicenter, randomized, double-blind, placebo-controlled, parallel-group study. Arthritis Rheum 2008;58:3319-3329.

47. Hauser SL, Waubant E, Arnold DL, et al. B-cell depletion with rituximab in relapsing-remitting multiple sclerosis. N Engl J Med 2008;358:676-688.
48. Keystone EC, Kavanaugh AF, Sharp JT, et al. Radiographic, clinical, and functional outcomes of treatment with adalimumab (a human anti-tumor necrosis factor monoclonal antibody) in patients with active rheumatoid arthritis receiving concomitant methotrexate therapy: a randomized, placebo-controlled, 52-week trial. Arthritis Rheum 2004;50:1400-1411.

49. Edwards JC, Szczepanski L, Szechinski J, et al. Efficacy of B-cell-targeted therapy with rituximab in patients with rheumatoid arthritis. N Engl J Med 2004;350:2572-2581.

50. Cohen SB, Moreland LW, Cush JJ, et al. A multicentre, double blind, randomised, placebo controlled trial of anakinra (Kineret), a recombinant interleukin 1 receptor antagonist, in patients with rheumatoid arthritis treated with background methotrexate. Ann Rheum Dis 2004;63:1062-1068.

51. Weinblatt ME, Keystone EC, Furst DE, et al. Adalimumab, a fully human anti-tumor necrosis factor alpha monoclonal antibody, for the treatment of rheumatoid arthritis in patients taking concomitant methotrexate: the ARMADA trial. Arthritis Rheum 2003;48:35-45.

52. Kremer JM, Westhovens R, Leon M, et al. Treatment of rheumatoid arthritis by selective inhibition of T-cell activation with fusion protein CTLA4Ig. N Engl J Med 2003;349:1907-1915.

53. Cohen S, Hurd E, Cush J, et al. Treatment of rheumatoid arthritis with anakinra, a recombinant human interleukin-1 receptor antagonist, in combination with methotrexate: results of a twenty-four-week, multicenter, randomized, double-blind, placebo-controlled trial. Arthritis Rheum 2002;46:614-624.

54. Weinblatt ME, Kremer JM, Bankhurst AD, et al. A trial of etanercept, a recombinant tumor necrosis factor receptor:Fc fusion protein, in patients with rheumatoid arthritis receiving methotrexate. N Engl J Med 1999;340:253-259.

55. Maini R, St Clair EW, Breedveld F, et al. Infliximab (chimeric anti-tumour necrosis factor alpha monoclonal antibody) versus placebo in rheumatoid arthritis patients receiving concomitant methotrexate: a randomised phase III trial. AT'TRACT Study Group. Lancet 1999;354:1932-1939.

56. Kremer JM, Dougados M, Emery P, et al. Treatment of rheumatoid arthritis with the selective costimulation modulator abatacept: twelve-month results of a phase iib, double-blind, randomized, placebo-controlled trial. Arthritis Rheum 2005;52:2263-2271.

57. Kremer JM, Genant HK, Moreland LW, et al. Effects of 
abatacept in patients with methotrexate-resistant active rheumatoid arthritis: a randomized trial. Ann Intern Med 2006;144:865-876.

58. Fleischmann RM, Halland AM, Brzosko M, et al. Tocilizumab inhibits structural joint damage and improves physical function in patients with rheumatoid arthritis and inadequate responses to methotrexate: LITHE study 2-year results. J Rheumatol 2013;40:113-126.

59. Lipsky PE, van der Heijde DM, St Clair EW, et al. Infliximab and methotrexate in the treatment of rheumatoid arthritis. Anti-Tumor Necrosis Factor Trial in Rheumatoid Arthritis with Concomitant Therapy Study Group. N Engl J Med 2000;343:1594-1602.

6o. Combe B, Codreanu C, Fiocco U, et al. Etanercept and sulfasalazine, alone and combined, in patients with active rheumatoid arthritis despite receiving sulfasalazine: a double-blind comparison. Ann Rheum Dis 2006;65:1357-1362.

61. Genovese MC, McKay JD, Nasonov EL, et al. Interleukin-6 receptor inhibition with tocilizumab reduces disease activity in rheumatoid arthritis with inadequate response to disease-modifying antirheumatic drugs: the tocilizumab in combination with traditional disease-modifying antirheumatic drug therapy study. Arthritis Rheum 2008;58:29682980.

62. Klareskog L, van der Heijde D, de Jager JP, et al. Therapeutic effect of the combination of etanercept and methotrexate compared with each treatment alone in patients with rheumatoid arthritis: double-blind randomised controlled trial. Lancet 2004;363:675-681.

63. Chatzidionysiou K, Emamikia S, Nam J, et al. Efficacy of glucocorticoids, conventional and targeted synthetic disease-modifying antirheumatic drugs: a systematic literature review informing the 2016 update of the EULAR recommendations for the management of rheumatoid arthritis. Ann Rheum Dis 2017;76:1102-1107.

64. Choe JY, Prodanovic N, Niebrzydowski J, et al. A randomised, double-blind, phase III study comparing SB2, an infliximab biosimilar, to the infliximab reference product remicade in patients with moderate to severe rheumatoid arthritis despite methotrexate therapy. Ann Rheum Dis 2017;76:58-64.

65. Emery P, Vencovsky J, Sylwestrzak A, et al. A phase III randomised, double-blind, parallel-group study comparing $\mathrm{SB} 4$ with etanercept reference product in patients with active rheumatoid arthritis despite methotrexate therapy. Ann Rheum Dis 2017;76:51-57.
66. Emery P, Fleischmann R, Filipowicz-Sosnowska A, et al. The efficacy and safety of rituximab in patients with active rheumatoid arthritis despite methotrexate treatment: results of a phase IIB randomized, double-blind, placebo-controlled, dose-ranging trial. Arthritis Rheum 2006;54:1390-1400.

67. Porter D, van Melckebeke J, Dale J, et al. Tumour necrosis factor inhibition versus rituximab for patients with rheumatoid arthritis who require biological treatment (ORBIT): an open-label, randomised controlled, non-inferiority, trial. Lancet 2016;388:239-247.

68. Coleman M, Lammers PE, Ciceri F, Jacobs IA. Role of rituximab and rituximab biosimilars in diffuse large B-cell lymphoma. Clin Lymphoma Myeloma Leuk 2016;16:175181.

69. Smolen JS, Han C, van der Heijde DM, et al. Radiographic changes in rheumatoid arthritis patients attaining different disease activity states with methotrexate monotherapy and infliximab plus methotrexate: the impacts of remission and tumour necrosis factor blockade. Ann Rheum Dis 2009;68:823-827.

70. Scott DL, Symmons DP, Coulton BL, Popert AJ. Longterm outcome of treating rheumatoid arthritis: results after 20 years. Lancet 1987;1:1108-1111.

71. van der Heijde DM, van Riel PL, van Leeuwen MA, van ‘t Hof MA, van Rijswijk MH, van de Putte LB. Prognostic factors for radiographic damage and physical disability in early rheumatoid arthritis: a prospective follow-up study of 147 patients. Br J Rheumatol 1992;31:519-525.

72. van Leeuwen MA, van Rijswijk MH, Sluiter WJ, et al. Individual relationship between progression of radiological damage and the acute phase response in early rheumatoid arthritis. Towards development of a decision support system. J Rheumatol 1997;24:20-27.

73. Goekoop-Ruiterman YP, de Vries-Bouwstra JK, Allaart $\mathrm{CF}$, et al. Comparison of treatment strategies in early rheumatoid arthritis: a randomized trial. Ann Intern Med 2007;146:406-415.

74. Kiely P, Walsh D, Williams R, Young A; Early Rheumatoid Arthritis Network. Outcome in rheumatoid arthritis patients with continued conventional therapy for moderate disease activity: the early RA network (ERAN). Rheumatology (Oxford) 2011;50:926-931.

75. Sieper J, Lenaerts J, Wollenhaupt J, et al. Efficacy and safety of infliximab plus naproxen versus naproxen alone in patients with early, active axial spondyloarthritis: results 
from the double-blind, placebo-controlled INFAST study, Part 1. Ann Rheum Dis 2014;73:101-107.

76. Song IH, Poddubnyy DA, Rudwaleit M, Sieper J. Benefits and risks of ankylosing spondylitis treatment with nonsteroidal antiinflammatory drugs. Arthritis Rheum 2008;58:929-938.

77. Callhoff J, Sieper J, Weiss A, Zink A, Listing J. Efficacy of TNF $\alpha$ blockers in patients with ankylosing spondylitis and non-radiographic axial spondyloarthritis: a meta-analysis. Ann Rheum Dis 2015;74:1241-1248.

78. Machado MA, Barbosa MM, Almeida AM, et al. Treatment of ankylosing spondylitis with TNF blockers: a meta-analysis. Rheumatol Int 2013;33:2199-2213.

79. Maxwell LJ, Zochling J, Boonen A, et al. TNF-alpha inhibitors for ankylosing spondylitis. Cochrane Database Syst Rev 2015;4:CDoo5468.

80. Rudwaleit M, Rødevand E, Holck P, et al. Adalimumab effectively reduces the rate of anterior uveitis flares in patients with active ankylosing spondylitis: results of a prospective open-label study. Ann Rheum Dis 2009;68:696-701.

81. Kornbluth A, Sachar DB; Practice Parameters Committee of the American College of Gastroenterology. Ulcerative colitis practice guidelines in adults: American College Of Gastroenterology, Practice Parameters Committee. Am J Gastroenterol 2010;105:501-523.

82. Lie E, Lindstrom U, Zverkova-Sandstrom T, et al. Tumour necrosis factor inhibitor treatment and occurrence of anterior uveitis in ankylosing spondylitis: results from the Swedish biologics register. Ann Rheum Dis 2017;76:1515-1521.

83. Lichtenstein GR, Loftus EV Jr, Isaacs KL, Regueiro MD, Gerson LB, Sands BE. Correction: ACG clinical guideline: management of Crohn's disease in adults. Am J Gastroenterol 2018;113:1101.

84. Hueber W, Sands BE, Lewitzky S, et al. Secukinumab, a human anti-IL-17A monoclonal antibody, for moderate to severe Crohn's disease: unexpected results of a randomised, double-blind placebo-controlled trial. Gut 2012;61:1693-1700.

85. Baeten D, Sieper J, Braun J, et al. Secukinumab, an interleukin-17A inhibitor, in ankylosing spondylitis. N Engl J Med 2015;373:2534-2548.

86. Sieper J, Deodhar A, Marzo-Ortega H, et al. Secukinumab efficacy in anti-TNF-naive and anti-TNF-experienced subjects with active ankylosing spondylitis: results from the MEASURE 2 Study. Ann Rheum Dis 2017;76:571-592.

87. Pavelka K, Kivitz A, Dokoupilova E, et al. Efficacy, safety, and tolerability of secukinumab in patients with active ankylosing spondylitis: a randomized, double-blind phase 3 study, MEASURE 3. Arthritis Res Ther 2017;19:285.

88. Deodhar A, Poddubnyy D, Pacheco-Tena C, et al. Efficacy and safety of ixekizumab in the treatment of radiographic axial spondyloarthritis: sixteen-week results from a phase iii randomized, double-blind, placebo-controlled trial in patients with prior inadequate response to or intolerance of tumor necrosis factor inhibitors. Arthritis Rheumatol 2019;71:599-611.

89. van der Heijde D, Cheng-Chung Wei J, Dougados M, et al. Ixekizumab, an interleukin-17A antagonist in the treatment of ankylosing spondylitis or radiographic axial spondyloarthritis in patients previously untreated with biological disease-modifying anti-rheumatic drugs (COAST-V): 16 week results of a phase 3 randomised, double-blind, active-controlled and placebo-controlled trial. Lancet 2018;392:2441-2451.

90. Breedveld FC, Weisman MH, Kavanaugh AF, et al. The PREMIER study: a multicenter, randomized, double-blind clinical trial of combination therapy with adalimumab plus methotrexate versus methotrexate alone or adalimumab alone in patients with early, aggressive rheumatoid arthritis who had not had previous methotrexate treatment. Arthritis Rheum 2006;54:26-37.

91. Scott IC, Ibrahim F, Simpson G, et al. A randomised trial evaluating anakinra in early active rheumatoid arthritis. Clin Exp Rheumatol 2016;34:88-93.

92. Choi M, Hyun MK, Choi S, et al. Comparative efficacy of biological agents in methotrexate-refractory rheumatoid arthritis patients: a Bayesian mixed treatment comparison. Korean J Intern Med 2017;32:536-547.

93. van der Heijde D, Klareskog L, Landewe R, et al. Disease remission and sustained halting of radiographic progression with combination etanercept and methotrexate in patients with rheumatoid arthritis. Arthritis Rheum 2007;56:3928-3939.

94. Emery P, Genovese MC, van Vollenhoven R, Sharp JT, Patra K, Sasso EH. Less radiographic progression with adalimumab plus methotrexate versus methotrexate monotherapy across the spectrum of clinical response in early rheumatoid arthritis. J Rheumatol 2009;36:1429-1441.

95. Burmester GR, Rigby WF, van Vollenhoven RF, et al. Tocilizumab in early progressive rheumatoid arthritis: FUNCTION, a randomised controlled trial. Ann Rheum Dis 2016;75:1081-1091. 
96. Baek HJ, Lim MJ, Park W, et al. Efficacy and safety of tocilizumab in Korean patients with active rheumatoid arthritis. Korean J Intern Med 2019;34:917-931.

97. Kaneko Y, Atsumi T, Tanaka Y, et al. Comparison of adding tocilizumab to methotrexate with switching to tocilizumab in patients with rheumatoid arthritis with inadequate response to methotrexate: 52-week results from a prospective, randomised, controlled study (SURPRISE study). Ann Rheum Dis 2016;75:1917-1923.

98. Dougados M, Kissel K, Conaghan PG, et al. Clinical, radiographic and immunogenic effects after 1 year of tocilizumab-based treatment strategies in rheumatoid arthritis: the ACT-RAY study. Ann Rheum Dis 2014;73:803-809.

99. Maini RN, Breedveld FC, Kalden JR, et al. Therapeutic efficacy of multiple intravenous infusions of anti-tumor necrosis factor alpha monoclonal antibody combined with low-dose weekly methotrexate in rheumatoid arthritis. Arthritis Rheum 1998;41:1552-1563.

100. Burmester GR, Kivitz AJ, Kupper H, et al. Efficacy and safety of ascending methotrexate dose in combination with adalimumab: the randomised CONCERTO trial. Ann Rheum Dis 2015;74:1037-1044.

101. Strangfeld A, Hierse F, Kekow J, et al. Comparative effectiveness of tumour necrosis factor alpha inhibitors in combination with either methotrexate or leflunomide. Ann Rheum Dis 2009;68:1856-1862.

102. Burmester GR, Mariette X, Montecucco C, et al. Adalimumab alone and in combination with disease-modifying antirheumatic drugs for the treatment of rheumatoid arthritis in clinical practice: the Research in Active Rheumatoid Arthritis (ReAct) trial. Ann Rheum Dis 2007;66:732-739.

103. Li EK, Griffith JF, Lee VW, et al. Short-term efficacy of combination methotrexate and infliximab in patients with ankylosing spondylitis: a clinical and magnetic resonance imaging correlation. Rheumatology (Oxford) 2008;47:1358-1363.

104. Marzo-Ortega H, McGonagle D, Jarrett S, et al. Infliximab in combination with methotrexate in active ankylosing spondylitis: a clinical and imaging study. Ann Rheum Dis 2005;64:1568-1575.

105. Schoels M, Aletaha D, Smolen JS, Wong JB. Comparative effectiveness and safety of biological treatment options after tumour necrosis factor $\alpha$ inhibitor failure in rheumatoid arthritis: systematic review and indirect pairwise meta-analysis. Ann Rheum Dis 2012;71:1303-1308.
106. Manders SH, Kievit W, Adang E, et al. Cost-effectiveness of abatacept, rituximab, and TNFi treatment after previous failure with TNFi treatment in rheumatoid arthritis: a pragmatic multi-centre randomised trial. Arthritis Res Ther 2015;17:134.

107. Torrente-Segarra V, Acosta Pereira A, Morla R, et al. VARIAR study: assessment of short-term efficacy and safety of rituximab compared to an tumor necrosis factor alpha antagonists as second-line drug therapy in patients with rheumatoid arthritis refractory to a first tumor necrosis factor alpha antagonist. Reumatol Clin 2016;12:319-322.

108. Smolen JS, Burmester GR, Combe B, et al. Head-to-head comparison of certolizumab pegol versus adalimumab in rheumatoid arthritis: 2-year efficacy and safety results from the randomised EXXELERATE study. Lancet 2016;388:2763-2774.

109. Carmona L, Ortiz A, Abad MA. How good is to switch between biologics? A systematic review of the literature. Acta Reumatol Port 2007;32:113-128.

110. Hyrich KL, Lunt M, Watson KD, Symmons DP, Silman AJ; British Society for Rheumatology Biologics Register. Outcomes after switching from one anti-tumor necrosis factor alpha agent to a second anti-tumor necrosis factor alpha agent in patients with rheumatoid arthritis: results from a large UK national cohort study. Arthritis Rheum 2007;56:13-20.

111. Caporali R, Sarzi-Puttini P, Atzeni F, et al. Switching TNF-alpha antagonists in rheumatoid arthritis: the experience of the LORHEN registry. Autoimmun Rev 2010;9:465-469.

112. Finckh A, Ciurea A, Brulhart L, et al. Which subgroup of patients with rheumatoid arthritis benefits from switching to rituximab versus alternative anti-tumour necrosis factor (TNF) agents after previous failure of an anti-TNF agent? Ann Rheum Dis 2010;69:387-393.

113. Gottenberg JE, Brocq O, Perdriger A, et al. Non-TNF-targeted biologic vs a second anti-TNF drug to treat rheumatoid arthritis in patients with insufficient response to a first anti-TNF drug: a randomized clinical trial. JAMA 2016;316:1172-1180.

114. Lie E, van der Heijde D, Uhlig T, et al. Effectiveness of switching between TNF inhibitors in ankylosing spondylitis: data from the NOR-DMARD register. Ann Rheum Dis 2011;70:157-163.

115. Deodhar A, Yu D. Switching tumor necrosis factor inhibitors in the treatment of axial spondyloarthritis. Semin 
Arthritis Rheum 2017;47:343-350.

116. Rudwaleit M, Van den Bosch F, Kron M, Kary S, Kupper H. Effectiveness and safety of adalimumab in patients with ankylosing spondylitis or psoriatic arthritis and history of anti-tumor necrosis factor therapy. Arthritis Res Ther 2010;12:R117.

117. Spadaro A, Punzi L, Marchesoni A, et al. Switching from infliximab or etanercept to adalimumab in resistant or intolerant patients with spondyloarthritis: a 4-year study. Rheumatology (Oxford) 2010;49:1107-1111.

118. Smolen JS, Breedveld FC, Burmester GR, et al. Treating rheumatoid arthritis to target: 2014 update of the recommendations of an international task force. Ann Rheum Dis 2016;75:3-15.

119. Smolen JS, Schols M, Braun J, et al. Treating axial spondyloarthritis and peripheral spondyloarthritis, especially psoriatic arthritis, to target: 2017 update of recommendations by an international task force. Ann Rheum Dis 2018;77:3-17.

120. Micic D, Komaki Y, Alavanja A, Rubin DT, Sakuraba A. Risk of cancer recurrence among individuals exposed to antitumor necrosis factor therapy: a systematic review and meta-analysis of observational studies. J Clin Gastroenterol 2019;53:e1-e11.

121. Wadstrom H, Frisell T, Askling J; Anti-Rheumatic Therapy in Sweden (ARTIS) Study Group. Malignant neoplasms in patients with rheumatoid arthritis treated with tumor necrosis factor inhibitors, tocilizumab, abatacept, or rituximab in clinical practice: a nationwide cohort study from Sweden. JAMA Intern Med 2017;177:1605-1612.

122. de La Forest Divonne M, Gottenberg JE, Salliot C. Safety of biologic DMARDs in RA patients in real life: a systematic literature review and meta-analyses of biologic registers. Joint Bone Spine 2017;84:133-140.

123. Chung ES, Packer M, Lo KH, Fasanmade AA, Willerson JT; Anti-TNF Therapy Against Congestive Heart Failure Investigators. Randomized, double-blind, placebo-controlled, pilot trial of infliximab, a chimeric monoclonal antibody to tumor necrosis factor-alpha, in patients with moderate-to-severe heart failure: results of the anti-TNF Therapy Against Congestive Heart Failure (ATTACH) trial. Circulation 2003;107:3133-3140.

124. Dixon WG, Watson KD, Lunt M, et al. Influence of anti-tumor necrosis factor therapy on cancer incidence in patients with rheumatoid arthritis who have had a prior malignancy: results from the British Society for Rheuma- tology Biologics Register. Arthritis Care Res (Hoboken) 2010;62:755-763.

125. Raaschou P, Simard JF, Holmqvist M, Askling J; ARTIS Study Group. Rheumatoid arthritis, anti-tumour necrosis factor therapy, and risk of malignant melanoma: nationwide population based prospective cohort study from Sweden. BMJ 2013;346:fi939.

126. Raaschou P, Frisell T, Askling J; ARTIS Study Group. TNF inhibitor therapy and risk of breast cancer recurrence in patients with rheumatoid arthritis: a nationwide cohort study. Ann Rheum Dis 2015;74:2137-2143.

127. Yun H, Xie F, Delzell E, et al. Risk of hospitalised infection in rheumatoid arthritis patients receiving biologics following a previous infection while on treatment with anti-TNF therapy. Ann Rheum Dis 2015;74:1065-1071.

128. Denis B, Lefort A, Flipo RM, et al. Long-term follow-up of patients with tuberculosis as a complication of tumour necrosis factor (TNF)-alpha antagonist therapy: safe re-initiation of TNF-alpha blockers after appropriate anti-tuberculous treatment. Clin Microbiol Infect 2008;14:183-186.

129. Toussirot E, Pertuiset E, Sordet C, et al. Safety of rituximab in rheumatoid arthritis patients with a history of severe or recurrent bacterial infection: observational study of 30 cases in everyday practice. Joint Bone Spine 2010;77:142-145.

130. Doran MF, Crowson CS, Pond GR, O'Fallon WM, Gabriel SE. Frequency of infection in patients with rheumatoid arthritis compared with controls: a population-based study. Arthritis Rheum 2002;46:2287-2293.

131. Bernatsky S, Habel Y, Rahme E. Observational studies of infections in rheumatoid arthritis: a metaanalysis of tumor necrosis factor antagonists. J Rheumatol 2010;37:928-931.

132. Singh JA, Cameron C, Noorbaloochi S, et al. Risk of serious infection in biological treatment of patients with rheumatoid arthritis: a systematic review and meta-analysis. Lancet 2015;386:258-265.

133. Kivitz AJ, Schechtman J, Texter M, Fichtner A, de Longueville $\mathrm{M}$, Chartash EK. Vaccine responses in patients with rheumatoid arthritis treated with certolizumab pegol: results from a single-blind randomized phase IV trial. J Rheumatol 2014;41:648-657.

134. Bingham CO 3rd, Rizzo W, Kivitz A, Hassanali A, Upmanyu R, Klearman M. Humoral immune response to vaccines in patients with rheumatoid arthritis treated with tocilizumab: results of a randomised controlled trial (VISARA). Ann Rheum Dis 2015;74:818-822. 
135. Bingham CO 3rd, Looney RJ, Deodhar A, et al. Immunization responses in rheumatoid arthritis patients treated with rituximab: results from a controlled clinical trial. Arthritis Rheum 2010;62:64-74.

136. Kaine JL, Kivitz AJ, Birbara C, Luo AY. Immune responses following administration of influenza and pneumococcal vaccines to patients with rheumatoid arthritis receiving adalimumab. J Rheumatol 2007;34:272-279.

137. Visvanathan S, Keenan GF, Baker DG, Levinson AI, Wagner CL. Response to pneumococcal vaccine in patients with early rheumatoid arthritis receiving infliximab plus methotrexate or methotrexate alone. J Rheumatol 2007;34:952-957.

138. Izumi Y, Akazawa M, Akeda Y, et al. The 23-valent pneumococcal polysaccharide vaccine in patients with rheumatoid arthritis: a double-blinded, randomized, placebo-controlled trial. Arthritis Res Ther 2017;19:15.

139. Migita K, Akeda Y, Akazawa M, et al. Effect of abatacept on the immunogenicity of 23-valent pneumococcal polysaccharide vaccination (PPSV23) in rheumatoid arthritis patients. Arthritis Res Ther 2015;17:357.

140. Elkayam O, Yaron M, Caspi D. Safety and efficacy of vaccination against hepatitis $\mathrm{B}$ in patients with rheumatoid arthritis. Ann Rheum Dis 2002;61:623-625.

141. Gotestam Skorpen C, Hoeltzenbein M, Tincani A, et al. The EULAR points to consider for use of antirheumatic drugs before pregnancy, and during pregnancy and lactation. Ann Rheum Dis 2016;75:795-810.

142. Casanova MJ, Chaparro M, Domenech E, et al. Safety of thiopurines and anti-TNF- $\alpha$ drugs during pregnancy in patients with inflammatory bowel disease. Am J Gastroenterol 2013;108:433-440.

143. Viktil KK, Engeland A, Furu K. Outcomes after anti-rheumatic drug use before and during pregnancy: a cohort study among 150,000 pregnant women and expectant fathers. Scand J Rheumatol 2012;41:196-201.

144. Cooper WO, Cheetham TC, Li DK, et al. Brief report: risk of adverse fetal outcomes associated with immunosuppressive medications for chronic immune-mediated diseases in pregnancy. Arthritis Rheumatol 2014;66:444-450.

145. Bortlik M, Machkova N, Duricova D, et al. Pregnancy and newborn outcome of mothers with inflammatory bowel diseases exposed to anti-TNF- $\alpha$ therapy during pregnancy: three-center study. Scand J Gastroenterol 2013;48:951-958.

146. Diav-Citrin O, Otcheretianski-Volodarsky A, Shechtman S, Ornoy A. Pregnancy outcome following gestational expo- sure to TNF-alpha-inhibitors: a prospective, comparative, observational study. Reprod Toxicol 2014;43:78-84.

147. Verstappen SM, King Y, Watson KD, et al. Anti-TNF therapies and pregnancy: outcome of 130 pregnancies in the British Society for Rheumatology Biologics Register. Ann Rheum Dis 2011;70:823-826.

148. Weber-Schoendorfer C, Oppermann M, Wacker E, et al. Pregnancy outcome after TNF- $\alpha$ inhibitor therapy during the first trimester: a prospective multicentre cohort study. Br J Clin Pharmacol 2015;80:727-739.

149. Mahadevan U, Wolf DC, Dubinsky M, et al. Placental transfer of anti-tumor necrosis factor agents in pregnant patients with inflammatory bowel disease. Clin Gastroenterol Hepatol 2013;11:286-292.

150. Schnitzler F, Fidder H, Ferrante M, et al. Outcome of pregnancy in women with inflammatory bowel disease treated with antitumor necrosis factor therapy. Inflamm Bowel Dis 2011;17:1846-1854.

151. Seirafi M, de Vroey B, Amiot A, et al. Factors associated with pregnancy outcome in anti-TNF treated women with inflammatory bowel disease. Aliment Pharmacol Ther 2014;40:363-373.

152. Luu M, Benzenine E, Doret M, et al. Continuous anti-TNF $\alpha$ use throughout pregnancy: possible complications for the mother but not for the fetus: a retrospective cohort on the French National Health Insurance database (EVASION). Am J Gastroenterol 2018;113:1669-1677.

153. Komoto S, Motoya S, Nishiwaki Y, et al. Pregnancy outcome in women with inflammatory bowel disease treated with anti-tumor necrosis factor and/or thiopurine therapy: a multicenter study from Japan. Intest Res 2016;14:139-145.

154. Ai JW, Zhang S, Ruan QL, et al. The risk of tuberculosis in patients with rheumatoid arthritis treated with tumor necrosis factor- $\alpha$ antagonist: a metaanalysis of both randomized controlled trials and registry/cohort studies. J Rheumatol 2015;42:2229-2237.

155. Solovic I, Sester M, Gomez-Reino JJ, et al. The risk of tuberculosis related to tumour necrosis factor antagonist therapies: a TBNET consensus statement. Eur Respir J 2010;36:1185-1206.

156. Cho KS. Tuberculosis control in the Republic of Korea. Epidemiol Health 2018;40:e2018036.

157. Kang YA, Lee HW, Yoon HI, et al. Discrepancy between the tuberculin skin test and the whole-blood interferon gamma assay for the diagnosis of latent tuberculosis infection in an intermediate tuberculosis-burden country. 
JAMA 2005;293:2756-2761.

158. Jung SM, Ju JH, Park MS, et al. Risk of tuberculosis in patients treated with anti-tumor necrosis factor therapy: a nationwide study in South Korea, a country with an intermediate tuberculosis burden. Int J Rheum Dis 2015;18:323-330.

159. Tubach F, Salmon D, Ravaud P, et al. Risk of tuberculosis is higher with anti-tumor necrosis factor monoclonal antibody therapy than with soluble tumor necrosis factor receptor therapy: the three-year prospective French Research Axed on Tolerance of Biotherapies registry. Arthritis Rheum 2009;60:1884-1894.

160. Dixon WG, Hyrich KL, Watson KD, et al. Drug-specific risk of tuberculosis in patients with rheumatoid arthritis treated with anti-TNF therapy: results from the British Society for Rheumatology Biologics Register (BSRBR). Ann Rheum Dis 2010;69:522-528.

161. Cantini F, Niccoli L, Goletti D. Tuberculosis risk in patients treated with non-anti-tumor necrosis factor- $\alpha$ (TNF- $\alpha$ ) targeted biologics and recently licensed TNF- $\alpha$ inhibitors: data from clinical trials and national registries. J Rheumatol Suppl 2014;91:56-64.

162. Ministry of Helalth and Welfare. The Fourth Korea National Health and Nutrition Examination Survey (KNHANES IV). Sejong (KR): Ministry of Helalth and Welfare, 2012.

163. Lee YH, Bae SC, Song GG. Hepatitis B virus reactivation in HBsAg-positive patients with rheumatic diseases undergoing anti-tumor necrosis factor therapy or DMARDs. Int J Rheum Dis 2013;16:527-531.

164. Perez-Alvarez R, Diaz-Lagares C, Garcia-Hernandez F, et al. Hepatitis B virus (HBV) reactivation in patients receiving tumor necrosis factor (TNF)-targeted therapy: analysis of 257 cases. Medicine (Baltimore) 2011;90:359-371.

165. Niitsu N, Hagiwara Y, Tanae K, Kohri M, Takahashi N. Prospective analysis of hepatitis $\mathrm{B}$ virus reactivation in patients with diffuse large B-cell lymphoma after rituximab combination chemotherapy. J Clin Oncol 2010;28:5097-5100.

166. Dong HJ, Ni LN, Sheng GF, Song HL, Xu JZ, Ling Y. Risk of hepatitis B virus (HBV) reactivation in non-Hodgkin lymphoma patients receiving rituximab-chemotherapy: a meta-analysis. J Clin Virol 2013;57:209-214.
167. Kim SJ, Hsu C, Song YQ, et al. Hepatitis B virus reactivation in B-cell lymphoma patients treated with rituximab: analysis from the Asia Lymphoma Study Group. Eur J Cancer 2013;49:3486-3496.

168. Hsu C, Tsou HH, Lin SJ, et al. Chemotherapy-induced hepatitis B reactivation in lymphoma patients with resolved HBV infection: a prospective study. Hepatology 2014;59:2092-2100.

169. Hsu CS, Lang HC, Huang KY, Lin HH, Chen CL. Association of rheumatoid arthritis and hepatitis $\mathrm{b}$ infection: a nationwide nested case-control study from 1999 to 2009 in Taiwan. Medicine (Baltimore) 2016;95:e3551.

170. Chen XQ, Peng JW, Lin GN, Li M, Xia ZJ. The effect of prophylactic lamivudine on hepatitis B virus reactivation in HBsAg-positive patients with diffuse large B-cell lymphoma undergoing prolonged rituximab therapy. Med Oncol 2012;29:1237-1241.

171. Hsu C, Hsiung CA, Su IJ, et al. A revisit of prophylactic lamivudine for chemotherapy-associated hepatitis B reactivation in non-Hodgkin's lymphoma: a randomized trial. Hepatology 2008;47:844-853.

172. Rossi G, Pelizzari A, Motta M, Puoti M. Primary prophylaxis with lamivudine of hepatitis B virus reactivation in chronic HbsAg carriers with lymphoid malignancies treated with chemotherapy. Br J Haematol 2001;115:58-62.

173. Raffeiner B, Grisan E, Botsios C, et al. Grade and location of power Doppler are predictive of damage progression in rheumatoid arthritis patients in clinical remission by anti-tumour necrosis factor $\alpha$. Rheumatology (Oxford) 2017:56:1320-1325.

174. Jung SM, Kwok SK, Ju JH, Park YB, Park SH. Risk of malignancy in patients with rheumatoid arthritis after anti-tumor necrosis factor therapy: results from Korean National Health Insurance claims data. Korean J Intern Med 2019;34:669-677.

175. Smolen JS, Aletaha D, Barton A, et al. Rheumatoid arthritis. Nat Rev Dis Primers 2018;4:18001.

176. Navarro-Compan V, Smolen JS, Huizinga TW, et al. Quality indicators in rheumatoid arthritis: results from the METEOR database. Rheumatology (Oxford) 2015;54:1630-1639. 